\title{
The Impact of Organizational Culture on the Adoption of E-Management "Evidence from Public Authority for Applied Education and Training (PAAET) in Kuwait"
}

\author{
Naser Almutairi ${ }^{1}$ \\ ${ }^{1}$ School of Management, college of business, Public Authority for Applied Education and Training (PAAET), \\ Kuwait \\ Correspondence: Naser Almutairi, Abullah Mubarak Block 1 Street 104 House 67, Kuwait. Tel: 965-9666-6514. \\ E-mail: kww666@yahoo.com
}

Received: July 2, 2014

doi:10.5539/ijbm.v9n9p57
Accepted: July 24, 2014

Online Published: August 22, 2014

\begin{abstract}
This study aimed to identify the "The Impact of organizational culture on the adoption of e- management" in the Public Authority for Applied Education and training (PAAET).The researcher used the descriptive analytical method, and collected primary data by a questionnaire, A (350) questionnaire distributed to employees dealing with the e-management in (PAAET), the Response was (300), and after examining the questionnaires (20) were excluded because of giving non-fulfillment of the conditions required to answer.

Study concluded numbers of results:

a) There are significant statistical positive correlation between the elements of an organizational cultural as (organizational values, organizational beliefs, organizational norms, and organizational expectations) and the adoption of e-Management.

b) The The employee can not make decisions within the culture of centralization in PAAET without reference to his immediate supervisor, even with the use of the framework of e-governance.

c) The management does not care or work on motivate staff for excellence in structuring and dissemination of e-Management in the PAAET.

d) The organazation culture is efected the staff participated in development e-management program.
\end{abstract}

Keywords: organizational culture, E-management

\section{Introduction}

\subsection{Contextual Background}

E-Management has been the main focus in the $21^{\text {st }}$ century since both individuals and organizations have adopted the internet, internet-based technologies and electronic-based technologies. Organizations have adopted these technologies in order to increase efficiency in their businesses, consequently increasing turnover, reducing costs, improving marketing and increasing profitability (Sharma, 2009). This has been achieved in highly developed countries. Developing countries these days are in a race towards catching up with these nations in business and thus the application of e-management in their institutions.

However, several educational institutions have started to raise the quality of education they offer in Kuwait. To do this, they have begun the improvement of management styles and other important aspects to better run the institutions. The application of electronic management has been considered in Kuwait as one of the areas that may help institutions to improve the quality of education they offer. Organizational culture is one of the key things that may assist or hinder the application of e-management. Many studies have been done on the importance of the application of e-management, the requirements of application, reality, their role in human resource management, and how to accept people for their services; however, few studies have addressed the role oforganizational culture in the application of e-management for doing business and administrative functions. This study will focus on the impact of organizational culture on the application of e-management featuring its reference from the PAAET.

In this study, the author will narrow the evaluation of the roles into organizational values, organizational beliefs, 
organizational expectations, and organizational regulatory norms present in the activation of the application of electronic governance in PAAET.

The Public Authority for Applied Education and Training (PAAET), an institution in Kuwait offering tertiary education, is gaining a lot interest in electronic management lately. It is slowly adopting the style in its management system. It has five colleges in the applied education sector while its training sector comprises of twelve institutes and centers (Ali, 2013).

PAAET recently adopted the electronic management system and has focused more on electronic document and records. With the current culture existing in the PAAET, questions have arisen regarding how the cultures will aid in the application of electronic management.

\subsection{Research Rationale}

The application of e-management in institutions in Kuwait has proven that e-management is the best style of management so far due to its advantages in institutions. Those which have applied e-management have seen great improvement in their management systems and their profit margins. These kinds of institutions are far ahead of those firms which have decided to ignore the technology. According to earlier researches, e-management application in a firm comes with many advantages over other systems. The future image of Kuwait is expected to flourish if institutions in Kuwait continue to adopt the new and efficient style of management (Al-Madhaf, 2012).

Institutional culture is effective when it comes to development. Rigid cultures are destructive to an institution. Organizational cultures should change to suit the changes in the growing world. That is how some countries like America have achieved their success.

The author makes the following consideration when choosing to study the impact of organizational culture on the adoption of e-management in the PAAET in Kuwait: Public Authority for Applied Education and Training does not run with the rigid form of culture as most of institutions in Kuwait. Their organizational culture is flexible and can easily adapt to global changes. PAAET has already started to apply e-management in their management system. The Public Authority for Applied Education and Training has a lot of employees from foreign countries who have affected the former culture in PAAET.

The PAAET is one of the few educational institutions in Kuwait. It is an institution of applied education and training so it is a very important institution in Kuwait regarding practical education. Its growth would mean the growth of Kuwait at large. This would increase the number of students helped by the institution to work after school in Kuwait.

An intensive literature review on the earlier studies about e-management and organizational culture will guide the evaluation of the best variable affecting the activation of application of electronic management in the PAAET.

\subsection{Research Aim and Objectives}

This research aims at analyzing the positive role of organizational culture in the adoption of e-management in Public Authority of Applied Education and Training in Kuwait.

The key objectives of the study include:

- To identify the nature of organizational culture prevailing in the PAAET.

- To identify the level of application of electronic management in the PAAET.

- To identify the most important variable influencing the organization positively towards the adoption of the e-management

- To provide recommendation to help senior management to enhance in the best way possible and the organization culture variables that help the application of electronic management in an effective and influential way.

\subsection{Hypothesis of the Study}

The study seeks to validate the following Hypothesis:

First hypothesis: There is a statistically significant relationship at the level of significance $(0.05)$ between organizational values in firms and adoption of the e-management.

Second hypothesis: There is a statistically significant relationship at the level of significance $(0.05)$ between organizational beliefs in organizations and adoption of the e-management

Third hypothesis: There is a statistically significant relationship at the level of significance (0.05) between 
organizational expectations in organizations and adoption of the e-management.

Fourth hypothesis: There is a statistically significant relationship at the level of significance $(0.05)$ between organizational norms in organizations and adoption of the e-management.

\subsection{Literature Review}

The literature review was gathered by evaluating previous researches on the application of electronic management, and the importance of culture in management. This will provide a theoretical understanding of the topic and provide a base for further research.

Little time has passed and in that moment, the world has seen mysterious development and renovation in information technology and communication. The application of this technology in business has turned modern management completely different from what was believed to be the reality of management in the past few years. The differences are evident in the changes that modern e-management has introduced. Business organisations all over the world which have adopted this style of management have experienced drastic changes in their structures, transactions and their standard of performance. In addition, this wonderful style of management has raised the efficiency of many organisations. Time, space, access to fast services, integrity and transparency are not a problem with the modern style (Hall, 2003).

The use of internet and business networks in the completion of planning, organising, leading, and surveying functions in schools and in many institutions is simply what is meant by electronic management. This style of completing an organisation's management functions is the latest. The completion of business aspects such as production, marketing, finance, personnel, development of processes and products through mail is what is meant by electronic management in companies (Kim, 2006). It requires change in style of the functioning of an organisation and the change in culture to facilitate changing market conditions, change in government policies, new technologies and other factors. An organisational culture poses a threat to the changes. However, organisational culture can also be advantageous in the application of e-management. Managing organisational culture is critical for bringing organisational values, beliefs, regulatory norms and organisational expectations to life, supporting the implementation of its strategies, promoting adaptation, goal attainment and sustainability (Cooke, 2002). Organisation culture is referred to us the behaviours that contribute to unique social and psychological environment of an organisation (organisational culture, 2012). It includes the organisation's expectations, experiences, philosophy, and values that holds it together. It is expressed in its inner workings, its self-image, interaction with the outside world, and future expectations. It is based on shared attitudes, custom and norms, beliefs and values (Cooke, 2002).

From what we have learned above, culture is an important aspect in guiding the behaviours of employees. It also assists in maintaining the identity group, cohesion of members and the survival of the respective group. It defines how things are going to be done in different situations in a whole organisation through a set of rules and regulations. It allows an active participation of all employees as a team and safeguards their interests (their family concerns, common values and goals) (Strategic Leadership and Decision Making, 2012). We can conclude then that organizational culture is vital in the determination of organisational success. According to Adeyoyin (2006), organisational culture plays an important role in the application and spreading of electronic management in an organisation.

\subsection{Variables of the Study}

Variables of the study are divided into independent and dependent variables. Dependent variables rely on other variables for change and existence. The dependent variable in this study is e-management. It relies on organizational culture. Independent variables exist and change all by themselves. This study's independent variable is the organizational culture which includes the following elements: organizational beliefs, organizational values, regulatory norms and regulatory expectations.

Organizational culture has an important influence on the behavior of individuals within the culture, even given their own unique situations and characteristics. Any attack on or resistance to the organization's cultural elements will face rejection. Consequently, organizational culture plays a significant role in resistance when individuals change from one setting to another within the organization. Culture works to both expand the horizons and frame the perceptions of individuals working within its environment. That is, the culture of the organization forms a frame of reference for the individual's interpretation of events and activities. Moreover, it helps to predict the behavior of individuals and groups. In general, when an individual is facing a particular situation or problem, he or she will act according to his or her culture; it is difficult to predict a person's behavior without any knowledge of the person's culture (Assaf, 2003, p. 124). The significance of organizational culture is that it provides a framework 
for organizing and directing organizational behavior, in the sense that the organizational culture affects employees and the behavior required of them within the organization. It is therefore concluded that organizational culture is characterized by a number of qualities which are shared among employees, can be learned, and can be passed on to new employees. It is important to recognize that no organization's culture is exactly like the culture of another, even if they are operating in the same sector. Every organization's culture develops along many different dimensions. For example, organizations differ with respect to the age of the organization; patterns of contacts; work systems and procedures; the process of the exercise of power; leadership style; and values and beliefs. If an organization wants to protect its culture, it constantly strives to attract employees who are compatible with its values, beliefs, and philosophy.

Al-Assaf reports a set of characteristics of organizational culture, including: 1) It helps to define standards of behavior and ensure compliance with company policies and values. With respect to the interaction between members of the organization, the culture imposes common standards of language (terms and phrases); behavior and conduct in terms of respect, actions, and the amount of work and needed to be done (do not work very much, not too little); and core values expected from employees, such as high quality, low rate of absenteeism, and compliance with regulations and instructions. 2) It provides a set of rules or instructions that vary in severity from one organization to another. The individual is expected to work in the organization according to these rules. 3) It helps to establish a "regulatory environment," that is, a set of properties that characterize the internal environment of the organization, affecting employees' values, attitudes, and perceptions, and providing a high degree of stability. These properties include a range of characteristics such as organizational structure, type of leadership, policies, procedures, laws and patterns, and contact. A strong organizational culture is critical to the effectiveness of the organizational sub-unit. A strong culture does not allow multiple disparate subcultures to develop, because these subcultures may not cooperate with each other, leading to organizational conflicts and decreasing organizational efficiency and performance. Martin \& Martol has confirmed that organizational culture has a positive impact on the organization, organizational behavior and organizational effectiveness when it is commonly and firmly established among employees (Assaf, 2003 , p. 127).

\subsubsection{Independent Variables}

Organizational beliefs. This is the shared ideas about the nature of work and social life in the working environment in business or any other institution. It includes the following: importance of employees working in a team and importance of active decision making towards achievement of the organization goals (Steen, 2013). The alignment of organization beliefs gives a path to the firm and has important implication for incentives and coordination (Steen, 2011).

Organizational values. 'Organizational values are underlying and the relatively stable dispositions which people use to guide their actions and decisions and to help them make judgment about what is right or wrong,' (Hyde, 2000). It normally determines 'compliance with legislation, employment, customer service, receiving gifts from suppliers and customers, rewarding customers, employees privacy and integrity, discrimination at work place and quality of service and products,' (Organizational Values and Standards, 2012).

Organizational norms. These are the standards set in an organization for every employee to adhere to. For example, standards such as not being away from the workplace for more than 6 hours.. Regulatory norms are essential for governing, defining and facilitating coordinated resource sharing and problem sharing in an organization (Kollingbaum, 2007).

Organizational expectations. This is an unwritten set of expectations on an individual or an organization. They are based on the image of an organization, the earlier performance, the size of the organization and the advantages of the organization's access (Knezvic, 2004).

\subsubsection{Dependent Variable}

E-management: The Concept of E-management : E-management is the style of managing business through systems, internet and electronics. This is the completion of management functions (planning, organising, decision making and controlling) using electronics, internet and systems means. It involves linking suppliers, customers, buyers, government bodies and organs and their respective competitors by the use of information technology. This is achieved by using information technology systems, electronics and networks installed in the particular organisation (Urban119, 2008).

Activities in offices in an organization with this style of management use information technology in their daily activities. It involves the use of a wide range of electrical gadgets and appliances, information technology systems and internet/intranet. This thus erases the assumptions of most of the people that e-management is the 
use of internet/intranet and file exchange to complete management functions (Crowley, 2008).

To add e-management involves the integration of data and information through information science technology. It is a flexible means of management because the data and information can be revised any time. It is tied together with modernization and civilization so it can be characterized as an efficient style of management (Srinivasan, 2001).

From the above, it can be concluded that e-management is a way that modern leaders are using intensive information technologies through integrated electronic systems based on information science to improve on the management functions through conversion of manual task power to digital task power which saves on power, expenses and time.

Electronic Management Tools: The electronic management activities use four management tools, the computer hardware, computer software, communication networks and the knowledge makers.

- Computer hardware: It is the mechanical part of the computer networks and accessories.

- Computer software: it is the invisible and the untouchable part installed in the computer hardware. It is divided into system software's for example network management, and OS and software applications such as e-mail, web browsers, electronic scale etc.

- Communication networks: These are the transmitters of information for example extranet, intranet and internet.

- Knowledge-makers: These are the information technology literate leaders, managers and analysts of cognitive resources and actually the capital to install the IT technologies in a firm.

Electronic Management Features: The feature of electronic management possesses the following characteristics:

- Wide scope interactions: It provides a potential smooth interaction and work anytime and anywhere with employees and/or customers.

- Real time interaction and clock: it operates with no time limit. The internet operates twenty four-seven to provide a real time interaction between employees and/or customers who may be in the organisation or anywhere else.

- Resource and teleworks: Institutions with internet is no longer interested in the border that separatesmaterial and human resources from others and consequently, the feature core business is to work without limits. The default activity is part of the institution's ability although teleworkers are partof the strength of the institution's work if they provide their services outside.

Advantages of E-management: According to Joshi (2012), e-management has the following advantages:

- Speed: The improved information technology makes communication faster and speedier. Internet, cell phones, computers and phones reduce the time taken in communication.

- Cost reduction: The cost of communication with IT is so cheap. The cost of sending a business mail is so little compared to a letter.

- Transparency: New technologies have made businesses to be more transparent than the future. They post all information about them and the public gets to learn about them.

- Accountability: Once a business process is made transparent, the business is automatically made accountable. It gains the trust of the customers.

- In addition, Alshehli (2013) says that e-management does not adhere to time and place. An employee can handle management issues even when away from the organization. Alshehli says that e-management allows flexibility. Management plans can be changed any time there is need as opposed to earlier signing of documents.

\subsection{Previous Studies}

According to a research done by O'Donnell and Boyle (2008), they explain that culture is important and public service managers should consider this in carrying out operations. The two said that there is a definite link between culture change and performance in an organisation. Companies undergoing a significant transformation or introducing major reforms change their culture traits to suit the transformation or the reform. To support this, they gave an example where people lost trust in Canadian public service because their culture change was influenced by corruption. 
According to Porta-Roth (2006), records and management system has moved to the top of every corporation's shortlist. There has been an explosive growth of electronic records and document management. In view of this trend, companies are assessing their documents and record management systems and found that: electronic documents and record management system is the only viable way to gain control over the number of records that are already existing and those that are created daily; record management can no longer be done in the older fashion; and the centralised back-office activity managed by a small group of small professional records and documents managers and clerks (Porta-Roth, 2006).

Porta-Roth Associates further gives the importance of integrating the electronic management system in the management of records and documents in any organisation. The company highlighted that e-management of documents and records bring administration and management of the system at central points. A headquarter of a branched organisation can assess documents and records of the branches easily which ensures ease of deployment. Record management is concentrated on literate and knowledgeable workers. They require minimal training and are flexible and adapts quickly to changes in user population. Accommodates new document technologies and documentation types; for example, text messaging, IM, and other emerging technologies. Lastly, the e-management document and record management system ensures document/record authenticity through its capability in sharing and transferring audit trail data.

Wilson (2012) addressed the realities of e-management through an in-depth research. In his research, he focused mostly on internet in business. Speed of coping with growth of internet and electronic technology in business application has been causing much difference between established companies. Some business organisations are posing a great threat to some other business organisations due to the skill gaps of their workers (Wilson, 2012).

Wilson explains e-mails as not so different from memos. Electronic invoice looks much like an on-screen version of its paper predecessor. He states that the internet is a new way of communication, a new channel of distribution, a market place, an information system, a tool for manufacturing goods and services. It makes a big difference in a range of activities which managers do every day (Wilson, 2012). Wilson points that the changes the internet brings in the business are simply more passive and varied than anything that goes before its introduction. Nearly every business management activity requires handling information in some form; a business plan, an instruction from senior managers to lower employees, a set of accounts, and general communication in the business firm. The introduction of internet and the improved technology in business makes this operation cheap, efficient and accurate.

Kuwait represents a collective culture as opposed to American and European countries which holds individualism. As described by Al Hunaiyyan (2008), collective cultures are interdependent and mainly focus on group identity, self-restraint and hierarchical control. This collective culture is less flexible to change. This collective culture collides indirectly with emerging trends and the growth in technology. The technology growth has to match with their culture so that they can welcome it.

\subsection{Difference of the Study from Previous Studies}

So many studies have been done on e-management and organizational culture as well as the advantages of e-management, application of e-management, etc. However, none of such studies have fully covered how organizational culture affects the activation of the application of e-management. This study focuses on the individual aspects of organizational culture. Earlier studies are more centred on organizational culture in general rather than its different aspects and features. This study seeks to know the difference in level of effects which different aspects of organisational culture pose to the activation of the application of e-management.

\section{Research Methodology}

Qualitative methods are used to analyze the data in this study .

The study will use qualitative methods to analyze the data collected. Quantitative method depended in numbers. This method assumes that reality is objective and hence uses cause and effects to test theories. Qualitative method on the other hand is more descriptive (Leech, 2012). The qualitative method emphasizes on understanding the complexity of interrelated and/or changing phenomena (Sofaer, 2009).

Analysis of the most important variable is more empirical and thus analyzed through qualitative method while evaluating the relationship between the organization culture and the adaption of the e-business in the PAAET.

\subsection{Sample}

As the research aims at exploring the organization culture and it effect in adaption e-business at Public authority of applied education and training, a relative large sample size is recommended. A larger sample size is, the more 
representative it can be, thus, the more reliable result is (Saunders et al., 2009, p. 219). Nevertheless, the sample size depends on researchers' available resources including time, finance and human (Saunders et al., 2009, p. 212). Questionnaires were delivered directly to employees in the PAAET. A sample of 350 employees was selected randomly which is represented 20 percent of the mature society. From 350 questionnaires were sent to individual. 300 responses in complete forms were returned and 20 responses were eliminated and 280 respond ware use for this study the response rate of $80 \%$, a moderate high rate for a postal questionnaire survey.

\subsection{Instrument}

The 5-point Likert scale, which are rating scale widely used for asking respondents' opinions and attitudes (Fisher, 2010, p. 214), is utilized to ask the individual auditors to evaluate the degrees of their agreement with the cause of conflict in the Public authority of applied education and training. The 5 points in the scale are respectively from 1 to 5: highly disagree, disagree, Neutral, agree, highly agree.

Data for this study was primary collected through a survey in form of a questionnaire. Primary data refers todata, which is collected for a specific purpose and which is required in order to complement secondary data(Wiedersheim-Paul \& Eriksson, 1997). Self-completion questionnaire seems to be one of the most commonmethods of quantitative researches. With a self-completion questionnaire, respondents answer questions bycompleting the questionnaire themselves. This method is chosen for some reasons. The first reason is that as theresearch questions are defined clearly, questionnaire is the best choice to have standardized data, which is easilyto process, and analyze. Especially, as no interviewers are present when the questionnaires are completing, theresults may not be affected by the interviewers (Zikmund, 2012). Moreover, it is cheaper thanother methods (Zikmund, 2012). Furthermore, this method helps to save time (Zikmund, 2012) so hundreds questionnaires can be sent out in one batch. As the respondents are auditors, they may not have much time for interviews, thus, questionnaires may make them feel more comfortable because they can do it whenever they have free time. Questionnaires also are more convenient for respondents in case they need to provide some sensitive information, in other words; they tend to be more honest than in an interview (Zikmund, 2012).

\subsection{Data Analysis Method}

In this research, the collected data were processed and analyzed using SPSS software. At first, the data were cleaned by removing questionnaires with poor quality data, including too many missing values or bias ratings. Then, statistical techniques included the Sign test and Cronbach's Alpha test. The reliability of each construct and its specific dimensions was appraised using Cronbach's a coefficients (Luu, 2010; Luu, 2012a).

\section{Results}

\subsection{Validity}

To establish the content validity of this instrument, the questionnaire was reviewed by ten experts who conducted an expert validity survey. After this review, invalid items were revised according to their comments and suggestions.

\subsection{Reliability}

Cronbach's alpha coefficient of reliability was calculated for the whole scale and for each dimension. The internal consistency estimate (alpha coefficient) of the total scale was .957, and the alpha coefficients for the dimensions ranged from .809 to .835 (Table 1). This demonstrates that the scale has strong internal consistency. According to Nunnally's (1978) reliability criteria, the whole scale was quite reliable. SPSS 17.0 software for Windows was used to analyze the data, including reliability analysis, descriptive statistics, arithmetic averages and test signal.

Table 1. Study dimensions with Cronbach's Alphas

\begin{tabular}{lll}
\hline Dimensions & No. of Items & Coefficient of Reliability $(\alpha)$ \\
\hline Organizational values & 8 & 0.813 \\
Organization beliefs & 10 & 0.834 \\
Organization norms & 13 & 0.809 \\
Organization expectations & 12 & 0.81 \\
E-Management & 11 & 0.835 \\
Whole scale & 54 & 0.957 \\
\hline
\end{tabular}




\subsection{Analysis of the Statements of the First Part: Demographic Characteristics}

The following are the results of the statistical analysis of the demographic characteristics of the study sample.

Table 2. Respondents' profiles

\begin{tabular}{llll}
\hline Variables & Categories & No. & $\%$ \\
\hline Gender & Male & 182 & 65 \\
& Female & 98 & 35 \\
\hline Age & 30 and younger & 78 & 27 \\
& $31-40$ & 100 & 36 \\
& $41-50$ & 60 & 22 \\
& 51 and older & 42 & 15 \\
\hline Social status & Married & 170 & 60.7 \\
& Single & 85 & 30.3 \\
& Divorced & 15 & 5.4 \\
& Widower & 10 & 3.6 \\
\hline Years of service & 5 years or less & 80 & 28.6 \\
& $6-10$ years & 90 & 32.1 \\
& 11-15 years & 60 & 21.4 \\
\hline Total & 16 years or more & 50 & 17.9 \\
\hline & & 280 & 100 \\
\hline
\end{tabular}

The distribution of respondents by gender table 2 shows that $65 \%$ of the study sample are male and that $35 \%$ are "female". This result reflects the high participation of women in the workforce over the past decade.

Distribution by age: Shows that $27 \%$ of the sample were "less than 30 years", $36 \%$ ranged in age from "30 to less than 40 years", $22 \%$ "from 40 to less than 50 years" and 15\% were of "50 years and more", indicating the diversity of members in the study. It is noted that $85 \%$ of the community study less than 50 years, which means that they are young and strong and capable of giving and being tender.

Distribution according to social status: Shows that $60.7 \%$ of the sample were "married", $30.3 \%$ "single", $5.4 \%$ "divorced", and 3.6\% were "widower". This is reflected in the nature of the society, where individuals have the financial stability to seek marriage and stability. In turn, this result gives a positive sign because the majority of the sample study have stable social and psychological aspects.

Distribution by number of years' service: Shows that $28.6 \%$ have "less than 5 years", $32.1 \%$ range "from 5 years to less than 10 years", $21.4 \%$ "of 10 years to less than 15 years", and $17.9 \%$ have more than "15 years" service.

\subsection{Analysis Using Arithmetic Averages and Test Signals}

\subsubsection{Analysis of the Second Part: Organizational Culture}

After reviewing Table 3, the arithmetic mean of the first distinction organizational values equal to 3.275 , and the arithmetic average relative to all the statements of the field is equal to $62.54 \%$. Moreover, the value of the test signal being 3.25 and p-value (Sig.) equal to 0.007 means that the organizational values are statistically significant at the level of significance $\alpha=0.05$. The average degree of response to this section differs substantially from the approved medium degree 3 , which means that there is a medium degree of approval by the members of the sample in the paragraphs of this section. There is an understanding in the work environment to the behaviours and attitudes supporting the e-business environment to an appropriate degree. In his study, Okasha (2008) highlights that workers must concern the accepted values that lead to an increased level of administrative efficiency.

After reviewing Table 4, the arithmetic mean of the second distinction beliefs regulatory is equal to 3.785 . The arithmetic average relative to all the paragraphs of an area equal is $72.054 \%$. The value of the test signal 12.813 
and p-value (Sig.) are equal to 0.000 . This considers the field of beliefs regulatory statistically significant at the level of significance $\alpha=0.05$. The average degree of response to this - the area being materially different from the degree of approval medium 3 (neutral) - means that there is a medium degree of approval by the members of the sample on the statements of this area. There are common ideas about the nature of work and social life in the work environment and how to complete such work and organizational tasks. In line with Okasha study (2008), which showed the presence of employee beliefs that job satisfaction contributes to the achievement of the tasks and duties of quality and efficiency, there is a belief in the importance of the development of working relationships between departments and various circles to embody the spirit of cooperation and integration while performing job tasks.

After reviewing Table 5 (see Appendix 1) the arithmetic mean is equal to 3.4234 and the arithmetic average relative to all the statements of the field is equal to $67.54 \%$. The value of the test signal was 6.54 and p-value (Sig.) equal to 0.000 , as that is the area of customs regulatory statistically significant at the level of significance $\alpha=0.05$. The average score on the response to this area is fundamentally different (degree approval medium 3 is neutral) and there is a fair degree of approval by the members of the sample. The employees are committed to the work environment standards and the norms fit the work environment to an acceptable degree, but still require development.

After reviewing Table 6 (see Appendix 1), the arithmetic mean is equal to 3.6223 and the arithmetic average relative to all the statements of the field is equal to $70.65 \%$. The value of the test signal is 11.89 and p-value (Sig.) equal to 0.000 , as that is the area of expected regulatory function statistically significant at the level of significance $\alpha=0.05$. The average degree of response in this area is materially different from the degree of approval medium (neutral). There is a fair degree of approval by the members of the sample in the paragraphs of this section. The expectations by the staff of the organization and what the organization expects of employees in the work environment is acceptable, but also requires development and is consistent with Okasha's (2008) study. That the workers who make the necessary effort in order to achieve expect the company, as well as the management of the company, to strive to meet the expectations of the company's employee bonuses, incentives and rewards.

In general, the arithmetic mean is equal to 3.5264 . The arithmetic average relative to all the statements of all distinctions is equal to $68.196 \%$, and the value of the test signal is 8.6232 and p-value (Sig.) equal to 0.000 . Therefore, organizational culture is statistically significant at the level of significance $\alpha=0.05$. The average score response differs substantially from the approved medium degree 3 (neutral), which means there is a medium degree of approval by the members of the sample on the statements in this area. The organization's culture has a role in the work environment, which is adhered to by the staff at the Public Authority of Applied Education and Training in Kuwait. The importance of senior management to encourage employees to participate in panel discussions and express their opinion on the values, beliefs, customs and expectations were prevailing within the institute to develop in a way that fits the work environment. To be disseminated to electronically, both permanently and continuously in the form of sentences, statements will reflect the organizational culture of the department and remind individuals.

3.4.2 Analysis of the Paragraphs of the Third Part: Activating the Application of E-Management in the Work Environment

After reviewing Table 7(see Appendix 1), the arithmetic mean for this distinction is equal to 3.4871 , the arithmetic average relative to all the paragraphs of the field is equal to $68.99 \%$, and the value of the test signal is 7.98 and p-value (Sig.) equal to 0.000 . For this, e-management activation is statistically significant at the level of significance $\alpha=0.05$. The average score on the response to this section differs substantially from the approved medium degree (neutral) and there is a fair degree of approval by the members of the sample. Senior management is working on adoption of the e-management in the work environment within the administrative body to an acceptable degree, but this requires development. This result is consistent with the results of the following studies, where senior management teams work on adopting e-management in an environment of administrative work:

-AL-Muqaira (2010) calls to amend administrative regulations and make them more flexible in line with the requirements of the application of e-governance.

-Al-Qahtani (2010) calls for the provision of human and material resources for implementation. 
Table 3. Organization values

\begin{tabular}{|c|c|c|c|c|c|c|}
\hline & Paragraph & $\begin{array}{l}\text { Average } \\
\text { Arithmetic }\end{array}$ & $\begin{array}{l}\text { Average } \\
\text { Arithmetic } \\
\text { Relative }\end{array}$ & $\begin{array}{l}\text { Value } \\
\text { Test }\end{array}$ & $\begin{array}{l}\text { Value } \\
\text { Probability } \\
\text { (Sig.) }\end{array}$ & rang \\
\hline 1 & $\begin{array}{l}\text { The administration consider the website as the core } \\
\text { of online presence of the ministry. }\end{array}$ & 3.846 & 76.10 & 12.5 & $* 0.000$ & 1 \\
\hline 2 & $\begin{array}{l}\text { The Employees are encouraged to develop new } \\
\text { ideas and progress by management }\end{array}$ & 3.5794 & 71.2 & 7.062 & $* 0.000$ & 3 \\
\hline 3 & $\begin{array}{l}\text { The Employees share information and technological } \\
\text { knowledge with each other, and they are open to } \\
\text { new ideas. }\end{array}$ & 3.628 & 69.82 & 8.95 & $* 0.000$ & 2 \\
\hline 4 & $\begin{array}{l}\text { The Department Interested in expanded the circle of } \\
\text { participation of employees in the process of taking } \\
\text { decisions of management within Environment of } \\
\text { e-business. }\end{array}$ & 3.0654 & 60.94 & 17.84 & 0.063 & 5 \\
\hline 5 & $\begin{array}{l}\text { The department gives the opportunity for staff to } \\
\text { explain and clarify the methods of creative invented } \\
\text { to develop systems and mechanisms of the } \\
\text { electronic program they use. }\end{array}$ & 3.0481 & 62.01 & 15.54 & 0.151 & 6 \\
\hline 6 & $\begin{array}{l}\text { The electronic Program is designed makes } \\
\text { employees more enjoyable and makes them feel that } \\
\text { what they are doing have value and meaning. }\end{array}$ & 3.515 & 70.54 & 74.12 & $* 0.000$ & 4 \\
\hline 7 & $\begin{array}{l}\text { The management staff involvement in the } \\
\text { development of proposals for forms and types of } \\
\text { services can be made available to the public. }\end{array}$ & 2.88 & 60.11 & -0.801 & 0.636 & 7 \\
\hline 8 & $\begin{array}{l}\text { I have been trained as an employee on methods } \\
\text { reduce the pressure resulting from the } \\
\text { electronic-work, such as meditation, relaxation, and } \\
\text { effective time management, and management of } \\
\text { lifestyle }\end{array}$ & 2.38 & 54.54 & -3.841 & $* 0.001$ & 8 \\
\hline \multicolumn{2}{|r|}{ Area with All Vertebrae } & 3.275 & 62.54 & 3.25 & $* 0.007$ & \\
\hline
\end{tabular}

Table 4. Organization beliefs

\begin{tabular}{|c|c|c|c|c|c|c|}
\hline & Paragraph & $\begin{array}{l}\text { Average } \\
\text { Arithmetic }\end{array}$ & $\begin{array}{l}\text { Average } \\
\text { Arithmetic } \\
\text { Relative } \\
\end{array}$ & $\begin{array}{l}\text { Value } \\
\text { Test }\end{array}$ & $\begin{array}{l}\text { Value } \\
\text { Probability } \\
\text { (Sig.) } \\
\end{array}$ & rang \\
\hline 1 & $\begin{array}{l}\text { There is a common conviction among staff of the } \\
\text { importance of participation in the decision-making } \\
\text { process. }\end{array}$ & 3.814 & 78.428 & 12.54 & $* 0.000$ & 4 \\
\hline 2 & $\begin{array}{l}\text { Employee has the necessary skills and abilities that } \\
\text { qualify him to accomplish his job by himself } \\
\text { without the need to clarify or inquiry of senior } \\
\text { management.. }\end{array}$ & 3.8382 & 78.51 & 12.054 & $* 0.000$ & 3 \\
\hline 3 & $\begin{array}{l}\text { Incentives and benefits links on the basis of what the } \\
\text { employee learned of the technical and technological } \\
\text { skills are necessary and useful for the job. }\end{array}$ & 2.9313 & 59.21 & -1.365 & 0.295 & 9 \\
\hline 4 & $\begin{array}{l}\text { Do you think that your system of administrative } \\
\text { paperwork has been transformed into an electronic } \\
\text { system work }\end{array}$ & 3.572 & 72.304 & 9.154 & $* 0.000$ & 7 \\
\hline 5 & $\begin{array}{l}\text { Administrative powers granted to you } \\
\text { commensurate with the way business is conducted } \\
\text { online, which depends on the speed of response and } \\
\text { accuracy of performance. }\end{array}$ & 3.647 & 73.514 & 10.021 & $* 0.000$ & 5 \\
\hline
\end{tabular}


6 management interested in introducing the problems

and challenges faced by the ministry and encourages

the employee to develops a new approaches to deal with it

7 E-services provided to the public via the Web site need to be developed and new additions.

8 Current developments introduced on the e-governance program was a product of the experiences of staff

9 Doing business electronically overcome the social phenomenon of lazing. AS some of the staff depending on their colleagues in the completion of the work assigned to them.

10 as an employee Consider getting things done electronically as a learning experience, which will acquire educational skills variety entitle you to succeed in your business

Area with All Vertebrae
3.102

61.48

79.422

73.25

3.625

3.4706

71.002

8.036

13.004

$* 0.000$

8.965

$* 0.000$

6

3.9123

77.906

13.084

$* 0.000$

2

Table 5. Organization norms

\begin{tabular}{|c|c|c|c|c|c|c|}
\hline & Paragraph & $\begin{array}{l}\text { Average } \\
\text { Arithmetic }\end{array}$ & $\begin{array}{l}\text { Average } \\
\text { Arithmetic } \\
\text { Relative } \\
\end{array}$ & $\begin{array}{l}\text { Value } \\
\text { Test }\end{array}$ & $\begin{array}{l}\text { Value } \\
\text { Probability } \\
\text { (Sig.) }\end{array}$ & rang \\
\hline 1 & $\begin{array}{l}\text { Norms prevailing among employees seeking to } \\
\text { adapt to technological advances developed in the } \\
\text { work environment }\end{array}$ & 3.833 & 76.12 & 21.245 & $* 0.000$ & 1 \\
\hline 2 & $\begin{array}{l}\text { Is committed to the most experienced staff and } \\
\text { experience in e-business to follow up and guide less } \\
\text { experienced colleagues and supervising } \\
\text { rehabilitation }\end{array}$ & 3.779 & 75.29 & 10.20 & $* 0.000$ & 2 \\
\hline 3 & $\begin{array}{l}\text { Norms prevailing among employees facilitated the } \\
\text { transition from traditional business to business }\end{array}$ & 3.675 & 72.55 & 10.42 & $* 0.000$ & 3 \\
\hline 4 & $\begin{array}{l}\text { Standards prevailing among the employees help to } \\
\text { create an atmosphere that promotes creativity and } \\
\text { innovation }\end{array}$ & 3.421 & 67.71 & 5.78 & $* 0.000$ & 9 \\
\hline 5 & $\begin{array}{l}\text { The staff is committed to standards that encourage } \\
\text { challenge and risk and open up new prospects for } \\
\text { completion of the work methods. }\end{array}$ & 3.276 & 64.10 & 3.51 & $* 0.003$ & 10 \\
\hline 6 & Managers look to the error as a source of learning. & 3.351 & 66.51 & 3.10 & $* 0.016$ & 8 \\
\hline 7 & $\begin{array}{l}\text { Prevailing norms help increase cooperation between } \\
\text { the staff. }\end{array}$ & 3.543 & 71.54 & 8.65 & $* 0.000$ & 4 \\
\hline 8 & $\begin{array}{l}\text { Management is committed to stimulate the creative } \\
\text { staff and distinguished moral and material } \\
\text { incentives }\end{array}$ & 2.923 & 57.41 & -2.98 & $* 0.005$ & 12 \\
\hline 9 & $\begin{array}{l}\text { Norms prevailing among staff working on the } \\
\text { activation of doing business electronically }\end{array}$ & 3.456 & 68.54 & 8.120 & $* 0.000$ & 7 \\
\hline 10 & $\begin{array}{l}\text { Management is committed to provide employees } \\
\text { with the necessary information to develop their use } \\
\text { of e-management applications }\end{array}$ & 3.466 & 68.54 & 6.87 & $* 0.000$ & 6 \\
\hline 11 & $\begin{array}{l}\text { Department works to encourage electronic best } \\
\text { practices among employees and between them } \\
\text { published as a role model. }\end{array}$ & 3.203 & 64.247 & 2.879 & $* 0.006$ & 11 \\
\hline 12 & $\begin{array}{l}\text { manager works to simplify and facilitate the } \\
\text { procedures for administrative work and is suitable } \\
\text { for the application of e-governance. }\end{array}$ & 3.521 & 69.54 & 6.52 & $* 0.000$ & 5 \\
\hline
\end{tabular}


13 Management is committed to publish success stories

2.90

65.74

$-1.822$

0.079

of employees, and to highlight their work and their

achievements as well as personal photographs on the

Ministry's website

Area with All Vertebrae

3.4234

67.54

6.54

$* 0.000$

Table 6. Organization expectations

\begin{tabular}{|c|c|c|c|c|c|c|}
\hline & Paragraph & $\begin{array}{l}\text { Average } \\
\text { Arithmetic }\end{array}$ & $\begin{array}{l}\text { Average } \\
\text { Arithmetic } \\
\text { Relative }\end{array}$ & ValueTest & $\begin{array}{l}\text { Value } \\
\text { Probability } \\
\text { (Sig.) }\end{array}$ & rang \\
\hline 1 & $\begin{array}{l}\text { Workers initiate to attend a self-qualification } \\
\text { technical courses in their desire to accommodate the } \\
\text { technical and technological developments relevant } \\
\text { to their work. }\end{array}$ & 3.842 & 77.01 & 12.420 & $* 0.000$ & 1 \\
\hline 2 & $\begin{array}{l}\text { Workers are able through the use of technology and } \\
\text { administrative powers delegated to respond quickly } \\
\text { to their tasks without taking instruction. }\end{array}$ & 3.7531 & 72.09 & 10.21 & $* 0.000$ & 2 \\
\hline 3 & $\begin{array}{l}\text { Administration plans to increase electronic channels } \\
\text { via the web page to allow public access to the } \\
\text { information it needs and enable them to manage. }\end{array}$ & 3.6342 & 72.81 & 8.97 & $* 0.000$ & 3 \\
\hline 4 & $\begin{array}{l}\text { The E-management gave the opportunity to the } \\
\text { employee responsible for the completion of the } \\
\text { work to take most of the decisions relating to work } \\
\text { without direct reference to the Boss }\end{array}$ & 3.4223 & 68.01 & 5.98 & $* 0.000$ & 9 \\
\hline 5 & $\begin{array}{l}\text { The Web site improved the real image of the } \\
\text { ministry by leaving a good impression to those of } \\
\text { the others. }\end{array}$ & 3.265 & 64.78 & 30.51 & $* 0.003$ & 10 \\
\hline 6 & $\begin{array}{l}\text { Doing business electronically gives the impression } \\
\text { of the fairly evaluate to the employee performance } \\
\text { and judgment on the exact level of achievement }\end{array}$ & 3.331 & 67.12 & 5.64 & $* 0.016$ & 8 \\
\hline 7 & $\begin{array}{l}\text { The employee is aware to which extent the breadth } \\
\text { cover of his duties, after his conversion to the } \\
\text { electronic style of work. }\end{array}$ & 3.654 & 71.54 & 8.98 & $* 0.000$ & 4 \\
\hline 8 & $\begin{array}{l}\text { Administration is working on expanding the circle } \\
\text { of staff participation in management } \\
\text { decision-making process within e-business } \\
\text { environment. }\end{array}$ & 2.981 & 65.47 & -2.894 & $* 0.005$ & 12 \\
\hline 9 & $\begin{array}{l}\text { e-business environment enabled employees to } \\
\text { complete their jobs accomplished electronically } \\
\text { period outside official working hours. }\end{array}$ & 3.456 & 69.21 & 7.210 & $* 0.000$ & 7 \\
\hline 10 & $\begin{array}{l}\text { You have no objection to responding to } \\
\text { work by email outside working hours. }\end{array}$ & 3.487 & 68.11 & 6.22 & $* 0.000$ & 6 \\
\hline 11 & $\begin{array}{l}\text { i Don't mind to complete the remainder of my duties } \\
\text { using the internet outside official working hours }\end{array}$ & 3.254 & 64.8 & 2.879 & $* 0.006$ & 11 \\
\hline 12 & $\begin{array}{l}\text { Doing business electronically to make every } \\
\text { employee responsible for the completion of the } \\
\text { work in the form of an integrated process and not } \\
\text { just part of it }\end{array}$ & 3.533 & 67.98 & 7.021 & $* 0.000$ & 5 \\
\hline \multicolumn{2}{|c|}{ Area with All Vertebrae } & 3.6223 & 70.65 & 11.89 & $* 0.000$ & \\
\hline
\end{tabular}


Table 7. E-management

\begin{tabular}{|c|c|c|c|c|c|c|}
\hline & Paragraph & $\begin{array}{l}\text { Average } \\
\text { Arithmetic }\end{array}$ & $\begin{array}{l}\text { Average } \\
\text { Arithmetic } \\
\text { Relative }\end{array}$ & $\begin{array}{c}\text { Value } \\
\text { Test }\end{array}$ & $\begin{array}{l}\text { Value } \\
\text { Probability } \\
\text { (Sig.) }\end{array}$ & rang \\
\hline 1 & $\begin{array}{l}\text { Department works to attract skilled experts in the } \\
\text { field of e-business. }\end{array}$ & 3.7443 & 74.5 & 10.01 & $* 0.000$ & 3 \\
\hline 2 & $\begin{array}{l}\text { public Are encourage to possess an official email to } \\
\text { communicate with the ministry }\end{array}$ & 3.8123 & 75.21 & 8.987 & $* 0.000$ & 2 \\
\hline 3 & $\begin{array}{l}\text { public Is motivated to integrate with the ministry } \\
\text { through the conversion of all the traditional business } \\
\text { to e-business can interact with it remotely by } \\
\text { electronic means. }\end{array}$ & 3.6874 & 72.98 & 9.79 & $* 0.000$ & 4 \\
\hline 4 & $\begin{array}{l}\text { employee's have their own electronic signature to } \\
\text { authenticate its electronic }\end{array}$ & 2.988 & 60.5 & -0.349 & 0.77 & 12 \\
\hline 5 & $\begin{array}{l}\text { Employees listed exchange success stories and } \\
\text { creativity on the experience of the transition to } \\
\text { electronic work in the ministry. }\end{array}$ & 3.132 & 62.18 & 1.231 & 0.345 & 11 \\
\hline 5 & $\begin{array}{l}\text { Managers enjoy fast motion response and initiative } \\
\text { in the implementation of their functions and duties } \\
\text { of administrative }\end{array}$ & 3.566 & 68.88 & 8.115 & $* 0.000$ & 6 \\
\hline 6 & $\begin{array}{l}\text { Leaders benefit from the feedback information } \\
\text { provided by the website of the Ministry for the } \\
\text { volume of transactions, preferences and public } \\
\text { needs }\end{array}$ & 3.543 & 67.86 & 7.995 & $* 0.000$ & 5 \\
\hline 7 & $\begin{array}{l}\text { You have been allow to access to the mail system } \\
\text { via the Internet while you are out of the workplace. }\end{array}$ & 3.879 & 77.54 & 11.510 & $* 0.000$ & 1 \\
\hline 8 & $\begin{array}{l}\text { Department provides to the public annotations } \\
\text { illustrative guidance and offers educational Power } \\
\text { Point for how to use the Web site and work e-mail } \\
\text { subscription. }\end{array}$ & 3.355 & 65.01 & 3.014 & $* 0.011$ & 9 \\
\hline 9 & $\begin{array}{l}\text { The management through electronic control provide } \\
\text { continuous feedback to the staff about their } \\
\text { performance }\end{array}$ & 3.232 & 64.10 & 2.14 & $* 0.037$ & 10 \\
\hline 10 & $\begin{array}{l}\text { Employees have enough time that allows them to } \\
\text { complete additional work if necessary }\end{array}$ & 3.4872 & 678.012 & 7.535 & $* 0.000$ & 7 \\
\hline 11 & $\begin{array}{l}\text { electronicand the devolution of powers push } \\
\text { administration to adopt a method of constant } \\
\text { electronic control. }\end{array}$ & 3.3765 & 64.76 & 5.987 & $* 0.000$ & 8 \\
\hline \multicolumn{2}{|c|}{ Area with All Vertebrae } & 3.4871 & 68.99 & 7.98 & \multicolumn{2}{|l|}{$0.000^{*}$} \\
\hline
\end{tabular}

\subsection{Test Hypotheses of the Study}

First hypothesis: There is a statistically significant relationship between organizational values and adoption of the e-management.

Spearman correlation coefficient was used to test the relationship between the paragraphs of the first domain "organizational values" and the paragraphs of Part III "adoption of the e-management". In order to test this hypothesis the results were as follows. 
Table 8 . The correlation coefficient between organizational values and adoption of the e-management

\begin{tabular}{lll}
\hline Area & Plants Spearman Correlation & Value Probability (Sig.) \\
\hline Organizational values & 0.701 & $* 0,001$ \\
\hline
\end{tabular}

Table 8 shows that the correlation coefficient between organizational values and activation of the application of e-management is equal to 0.701 , and the p-value (Sig.) equal to 0.001 , which is less than the significance level $\alpha$ $=0.05$. This indicates the presence of positive correlation and statistically significant differences between organizational values and adoption of the e-management.

Second hypothesis: There is a statistically significant relationship between organizational beliefs and adoption of the e-management.

This hypothesis tested the relationship between the paragraphs of the second area "organizational beliefs" and the paragraphs of Part III "adoption of the e-management".

Table 9. The correlation coefficient between the organizational beliefs and adoption of the e-management

\begin{tabular}{lll}
\hline Area & Plants Spearman Correlation & Value Probability (Sig.) \\
\hline Organizational Beliefs & 0.611 & $* 0,000$ \\
\hline
\end{tabular}

Table 9 shows that the correlation coefficient between organizational beliefs and adoption of the e-managementis equal to 0.611 and $\mathrm{p}$-value ( $\mathrm{Sig}$ ) equal to 0.000 , which is less than the significance level $\alpha=0.05$. This indicates the existence of positive correlation differences between organizational beliefs and adoption of the e-management.

Third hypothesis: There is a statistically significant relationship between organizational norms and adoption of the e-management.

This hypothesis tested the relationship between the paragraphs of the third area " organizational norms " and the paragraphs of Part III " adoption of the e-management".

Table 10. The correlation coefficient between the organizational norms and adoption of the e-management

\begin{tabular}{lll}
\hline Area & Plants Spearman Correlation & Value Probability (Sig.) \\
\hline organizational norms & 0.780 & $* 0,000$ \\
\hline
\end{tabular}

Table 10 shows that the correlation coefficient between organizational norms and adoption of the e-management is equal to 0.780 and $p$-value (Sig.) equal to 0.000 , which is less than the significance level $\alpha=0.05$. This indicates the presence of positive correlation that there are statistically significant differences between norms organizational norms and adoption of the e-management.

Fourth hypothesis: There is a statistically significant relationship between organizational expectations and adoption of the e-management.

This hypothesis tested the relationship between the paragraphs of the fourth area " organizational expectations " and the paragraphs of Part III "to adoption of the e-management".

Table 11. The correlation coefficient between the organizational expectations and adoption of the e-management

\begin{tabular}{lll}
\hline Area & Plants Spearman Correlation & Value Probability (Sig.) \\
\hline organizational expectations & 0.801 & $* 0,000$ \\
\hline
\end{tabular}

Table 11 shows that the correlation coefficient between the organizational expectations and adoption of the e-management is equal to 0.801 and p-value (Sig.) equal to 0.000 , which is less than the significance level $\alpha=$ 0.05 . This indicates the presence of positive correlation statistically significant differences between 
organizational expectations and adoption of the e-management.

\section{Discussion}

Based on the field study conducted by a researcher on the role of organizational culture in the activation of the application of e-management, among the staff of the Public Authority for Applied Education and Training, the following conclusions were reached:

1) There is a statistically significant relationship between organizational values and adoption of the e-management, and the direct correlation of this relationship. This relationship is due to organizational values prevailing in the body:

- Works to guide the behaviour of staff to interact with e-business systems.

- Encourage employees to develop new ideas to fit the work environment.

- Determine staff outlines of their activities and their daily practices.

- The expansion of employee participation in management decision-making related to their work.

- Provide an environment where employees share information and technological knowledge needed to increase their technical skills within the work environment of e-management.

2) There is a statistically significant relationship between organizational beliefs and adoption of the e-management. This relationship was a direct correlation and based on the outcomes which highlight that this relationship is due to the belief that the prevailing regulatory body:

- That qualified staff carry out their jobs themselves, indicating their understanding of the requirements of their jobs, and the perception that they are able to do so in the electronic business environment. Pushing for the strengthening of function points and delegated administrative powers necessary to convert them into points and strong functional elements.

- Staff feeling that their traditional administrative paperwork has been transformed into an electronic business system, which enhances their convictions to move to the way business is conducted electronically.

- The existence of the convictions of the need for the administration to develop a website and expand the adoption of the attic in communicating with students, and to enable staff to access the environment through portals. This works to abolish the barriers of space and time in the interaction with students and staff.

- Staff believe the emergence of a particular language within the work environment, including electronic exchange in its vocabulary to express the work they do. This increases interactions with the business and enhances individuals' sense of privacy and their functional environment differentiating them from others.

- Feeling that the staff may overcome the social phenomenon of lazing through the dependence of some of their colleagues to accomplish their work assigned to them. Therefore, each employee will receive a user name and password to reach his own environment.

3) There is a statistically significant relationship between organizational norms and adoption of the e-management, and the direct correlation of this relationship based on what can be stated bring the conclusion that this relationship is due to the prevailing regulatory norms in the authority:

- Support the staff and encourage them to adapt to the technological developments that have been developed in their work environment, which helps to speed their integration into the e- business environment.

- Encourage the most experienced staff to supervise less experienced colleagues and follow up and guide them down to their stage of development, as part of a work environment ever-evolving electronic imposed on dealers with time of development and progress, and learning to absorb all new individuals.

- Support increased cooperation between staff in order to create an environment conducive to the growth of teams that are committed to achieving the goals, which works to increase the effectiveness of e-management.

- Encourage managers to take notice of simplifying and facilitating the procedures of administrative work, avoid the complexities and cons of the system bureaucrats, and to overcome them through an e-working style.

- Work through the administration to pay attention to encouraging the best practices of electronic dissemination among employees and among them as a model in the completion of their work. 
4) There is a statistically significant relationship between organizational expectations and adoption of the e-management, and the direct correlation of this relationship. Based on what can be stated, the conclusion is that this relationship is due to expectations that the prevailing regulatory body will:

- Encourage employees to take the initiative to self-enrol in courses of technological training in their desire to accommodate the technical and technological developments related to their work.

- Create a reluctance among employees not to respond to work email outside working hours, where an electronic work environment is related to the period of work or place of work.

- Push the administration to enable staff to complete and accomplish their jobs electronically from outside the workplace and allow them access to their electronic environment through the Internet.

- Encourage the administration to enable employees to be responsible for the delivery of a currency in the form of an integrated process and not just part of it, and therefore achievement is actively linked to the others but its activity is just.

- Reinforce the feeling and employee awareness of the breadth of coverage and the extent to which the duties of his or her job after the shift to e-work style.

- Improve the feeling of staff within the e-business environment, management's assessment of the fairness of their performance, and increase their ability to rule on the exact size and level of achievement of their careers. The way business is conducted electronically documents where everything is at any one time.

- Help the administration provide services across the biggest web pages and provide more information needed by the body, whether dealing with students or employees.

- Attention given to administrative procedures, study and work on simplifying the work environment to activate the e-management. Also, attention given to the definition of employee problems and challenges faced by the body, and push them to form creative solutions to enable them to deal with them in innovative ways.

\section{Recommendations of the Study}

The recommendations can be summarized and emphasized by the researcher as follows:

- That the Ministry's website represents the identity of the body and its mission and strategy, as well as its activities and services, and is more than just an electronic interface.

- Sort integrated team skills to manage the Ministry's website under the supervision of senior management.

- Encourage individuals with the Commission on the possession of an official email and Review Commission through its website, with explanatory annotations to provide educational guidance on how to use the site.

- Follow the needs of staff and students and increase electronic channels via the website, which allows access to information and responds to needs and enables them to manage them.

- Maintain the continued development of the e-work programme with support from senior management and the development of special forms of action.

- Encourage employees to apply for management proposals for the development of an e-work programme and put forward ideas for a new business with complete freedom to take advantage of the expertise of faculty members.

- Ensure the free movement of information and knowledge, and participation among employees.

\section{Proposals for Future Studies}

- The role of planning in mail management decision-making in contemporary organizations.

- The requirements and constraints of the success of the electronic control system.

- The effectiveness of the electronic control system in the evaluation of the performance of employees.

- The role of knowledge management in the activation of the application of e-governance.

- The impact of e-governance on the development of organizational structures in public institutions.

\section{References}

Adeyoyin, S. O. (2006). Managing the library's corporate culture for organizational efficiency, productivity, and enhanced service. Library Philosophy and Practice, 8, 1-8.

Alabama State Parks. (2013). Gulf State Park. Retrieved from http://www.alapark.com/gulfstate/ 
Al-Assaf, S. H. (2003). The introduction to research in Behavioral Sciences (3rd ed.). Riyadh: Obeikan Bookstore.

AL-Hunaiyyan, A. (2008). Discussion of cultural issues. Blended E-Learning Design, 1, 17-32.

Ali, K. A. (2013). The Kuwaiti distance. Automating PAAET, 1-14.

Al-Mudhaf, H. M. (2012). KUWAIT. World Trade. Retrieved from http://www.wto.org/english/thewto_e/minist_e/min96_e/st43.htm

AL-Muqaira, F. A. A. (2010). Obstacles to the application of e-governance in the procedures of administrative work from the perspective of the staff of the Office of Ministry Saudi Interior. Master Thesis, unpublished, electronic version, Naif Arab University for Sciences of security, Riyadh, Saudi Arabia Retrieved from http://www.nauss.edu.sa/Ar/DigitalLibrary/ScientificTheses/Documents/m_as_16_2010.pdf

Al-Qahtani, A, B., \& Ahmed, M. (2010). Areas of application of electronic transactions and constraints in the Emirate of Riyadh region. Thesis, unpublished, electronic version. Naif Arab University for Security Sciences, Riyadh, Saudi Arabia Retrieved form http://www.nauss.edu.sa/Ar/DigitalLibrary/ScientificTheses/Documents/m_as_30_2010.pdf

Alshehri, M. (2013). Implementation of e-government: Advantages and challenges. Retrieved from http://www.academia.edu/1007717/Implementation_of_e-Government_Advantages_and_Challenges

Better Evaluation. (2012). Combine qualitative and quantitative data. Retrieved from http://betterevaluation.org/plan/describe/combining_qualitative_and_quantitative_data

Business Dictictionary. (2013). Organisational culture. Retrieved from http://www.businessdictionary.com/definition/organizational-culture.html

Cooke, R. A. (2002). Organizational culture inventory. Human Synergistics International. Retrieved from http://www.humansynergistics.com/Products/OrganizationDevelopment/OrganizationalCultureInventory

Crowley, M. (2008). E-governance. Policy Perspectives. Retrieved from http://www.imakenews.com/cppa/e_article001132589.cfm

Hall, P. (2003). Managing the digital firm. Essentials of Management and Information Systems, 1-44.

Hyde, P. (2000). The importance of organisational values. Focus on Change Management, 68, 10-14.

Independence Commission Against Corruption. (2012). Organisational values and standards. Retrieved from http://www.icac.nsw.gov.au/preventing-corruption/foundations-for-corruption-prevention/standards-and-val ues $/ 4873$

Joshi, A. A. (2012). Advantages of e-governance. E-Governance in India. Retrieved from $\mathrm{http}: / /$ indiaegovernance.blogspot.com/2008/03/advantages-of-e-governance.html

Kim, Y. G. (2006). Knowledge sharing in virtual communities: An e-business perspective. Pergamon, 155-168.

Knezevic, D. I. (2004). Guidelines on regulatory expectations related to the elimination, reduction or replacement of thiomersal in vaccines. Annex, 96-100.

Kollingbaum, M. J. (2007). Resolving conflict and inconsistency in norm-regulated virtual organic. The ACM Guide to Computing Literature, 2.

Leech, N. L. (2012). A call for data analysis triangulation. An Array of Qualitative Data Analysis Tools, 558-582.

Mark.(2011). Kuwait 14th richest country in the world. Two Forty Eight The A-Sides. Retrieved from http://248am.com/mark/kuwait/richest-and-poorest-countries-in-the-world/

Millar, L. (2009). Managing the creation, use and disposal of electronic records. International Records Management Trust, 2-74.

Milne, J. (1999, March 25). Questionnaires: Advantages and Disadvantages. Evaluation Cookbook. Retrieved from http://www.icbl.hw.ac.uk/ltdi/cookbook/info_questionnaires/

National Defence University. (2012).Strategic leadership and decision making. Retrieved from http://www.au.af.mil/au/awc/awcgate/ndu/strat-ldr-dm/pt4ch16.html

O’Donnell, O. (2008). Understanding and Managing. CPMR Discussion Paper, 1-87.

Okasha, A. A. M. (2008). Impact of organizational culture on the level of job performance: An Empirical Study on Communications Company in Palestine. Unpublished MA Thesis, an electronic version, the Islamic 
University, Gaza, Palestine. Retrieved from http://library.iugaza.edu.ps/Thesis1.aspx

Porter-Roth, B. (2006). Applying electronic records management. Xerox Docu Share, 2-16.

Rainwater, D. (2013). The advantages of a questionnaire. eHOW. Retrieved from http://www.ehow.com/info_8288573_advantages-questionnaire-research-project.html

Sharma, S. (2009). International Journal of E-Adoption (IJEA). Retrieved from http://www.igi-global.com/journal/international-journal-adoption-ijea/1107

Shehab, M. (2012). Electronic document delivery. e-lis Print in Library \& Information Science. Retrieved from http://eprints.rclis.org/7305/1/Paper.html

Sofaer, S. (2009, November 9). Methodological challenge. United States Department of Veterans Affairs. Retrieved from http://www.colmr.research.va.gov/mgmt_research_in_va/methodology/qualitative_research.cfm

Srinivasan, D. R. (2001, February 12). Architectural characteristics for e-governance. Express Computers. Retrieved from http://icmgworld.com/corp/news/articles/rs/11a.asp

Steen, E. V. (2011). Organizational beliefs and managerial vision. Massachusetts Institute of Technology, 1-22.

Steen, E. V. (2013). Organizational beliefs and managerial vision. The Journal of Law, Economics and Organisation, 256-283.

Stolley, K. (2013, February 14). Primary research. OWL Purdue Online Writing Lab. Retrieved from http://owl.english.purdue.edu/owl/resource/552/04/

The Times 100 Business Case Studies. (2013). Providing a customer-centric service. Retrieved from businesscasestudies.co.uk/zurich/providing-a-customer-centric-service/secondary-research.html\#axzz2TZm AL2hP

Travel. State. Gov. (2013). Kuwait country specific information. Retrieved from http://travel.state.gov/travel/cis_pa_tw/cis/cis_944.html

Trochim, W. M. (2006). Sampling. Research Methods Knowledge Base. Retrieved from http://www.socialresearchmethods.net/kb/sampling.php

urban119. (2008). E-government: Its characteristics, practices and future. Study mode. Retrieved from http://www.studymode.com/essays/E-Government-Its-Characteristics-Practices-Future-170073.html

Wilson, D. C. (2012).Inside the machine. The Economist. Retrieved from http://www.economist.com/node/416998

Zikmund, W. G. (2012). Business research methods (9th ed.). Mason, OH: Erin Joyner.

\section{Copyrights}

Copyright for this article is retained by the author(s), with first publication rights granted to the journal.

This is an open-access article distributed under the terms and conditions of the Creative Commons Attribution license (http://creativecommons.org/licenses/by/3.0/). 